\title{
Stabilization Factor for Enterprises during the Crisis Period
}

\author{
Svetlana Grigashkina ${ }^{1, *}$, Olga Garafonova $^{2}$, and Victoriya Marhasova $^{3}$ \\ ${ }^{1}$ T.F. Gorbachev Kuzbass State Technical University \\ ${ }^{2}$ Kyiv National Economics University named after Vadym Hetman \\ ${ }^{3}$ Chernihiv National University of Technology
}

\begin{abstract}
Market conditions of the business determine the information and contractual relations with the basic attributes of doing business. Information support of business forms the system of communications of the enterprise as an open system, on the basis of which the environment of functioning of the enterprise is formed, where its employees interact with suppliers, consumers, intermediaries, partners. The system for establishing such interactions is determined by the communicative policy of the enterprise, the formation and management of which is a complex, laborintensive and relevant process in the market economy. The purpose of the work is to study the peculiarities of the marketing communication policy of enterprises under the influence of crisis phenomena.
\end{abstract}

\section{Introduction}

In the general sense communication policy is the exchange of information messages between two and more people using a variety of means. While marketing communications are considered as a process of product promotion, providing product information and maintaining customer relationships [1].

The whole set of enterprise communications can be classified in four ways:

- at the place of performance (with the external environment, inside the organization);

- by type of communication (formal, informal);

- on the direction of communications (vertical, horizontal);

- in the form of communication (subordinate leader, leader-group, equal).

\section{Materials and Methods}

Among communications, marketing ones are distinguished by specific tools that are determined by the coordination in the system "advertising - personal sales - propaganda direct marketing - public relations - sales promotion", the characteristics, common and distinctive features between the elements are presented in Table 1 and 2 [2-3].

\footnotetext{
*Corresponding author: grigashkina_si@mail.ru
} 
Marketing communications perform one of the key functions of ensuring the development of an enterprise, because the information that marketing communications hold depends on the attitude of consumers, partners, suppliers, the public towards the enterprise and its products of its activities.

Table 1. Characteristics of elements of marketing communications.

\begin{tabular}{|c|c|}
\hline $\begin{array}{l}\text { Advertising } \\
\text { - expressive character, opportunity } \\
\text { to effectively submit goods to the firm; } \\
\text { - mass audience coverage; } \\
\text { - the possibility of multiple use, the ability } \\
\text { to persuade and persuade; } \\
\text { - social character; } \\
\text { - the need for large allocations. }\end{array}$ & $\begin{array}{l}\text { Personal Sales } \\
\text { - personal character; } \\
\text { - direct, live communication with the } \\
\text { audience in the form of dialogue; } \\
\text { - coercive response; } \\
\text { - the highest value among all means of } \\
\text { communicative policy per one contact. }\end{array}$ \\
\hline $\begin{array}{l}\text { Propaganda } \\
\text { - intense character; } \\
\text { - Individual, not mass audience coverage, } \\
\text { the possibility of one-time use; } \\
\text { - the most effective compulsion to } \\
\text { purchase; } \\
\text { - high degree of trust in the information } \\
\text { provided. }\end{array}$ & $\begin{array}{l}\text { Direct marketing } \\
\text { - personal character; } \\
\text { - high reliability of information and } \\
\text { confidence in its audience; } \\
\text { - impulsive character; } \\
\text { - a long-lasting effect aimed at forming a } \\
\text { stable customer loyalty to one trade mark; } \\
\text { - direct communication with people. }\end{array}$ \\
\hline $\begin{array}{l}\text { Public relations } \\
\text { - high reliability of information, trust in it } \\
\text { consumers, because it is presented in the } \\
\text { form of news, not ads; } \\
\text { - coverage of a wide audience; } \\
\text { - impossibility to control the content of } \\
\text { information by the enterprise; } \\
\text { - rarely exists independently without } \\
\text { advertising. }\end{array}$ & $\begin{array}{l}\text { Sales promotion } \\
\text { - the attractiveness of sales promotion } \\
\text { measures } \\
\text { from consumers; } \\
\text { - short-acting effect, which is unacceptable } \\
\text { for forming a stable devotion to one brand. }\end{array}$ \\
\hline
\end{tabular}

Therefore, the main tasks of communicative policy are:

- formation of a communicative strategy of the enterprise with clearly defined goals and consistent measures for their implementation;

- formation of a positive image of the enterprise and its products;

- informing the market about existing and new products of the enterprise, peculiarities of their application and advantages, price policy;

- conducting research on the needs and purchasing power of the population;

- advertising promotion of products of the enterprise;

- informing the market about conditions of sales promotion;

- convincing potential buyers to expedite the purchase of products of activity this particular enterprise;

- providing feedback to consumers.

With the conditions for the spread of crisis phenomena in the enterprise among the mechanisms of corporate governance, the system of anti-crisis communication policy takes the first place\& It should contribute to the formation of a positive information background around the enterprise. The fundamental reason for the emergence of crisis phenomena in the enterprise is the realization of the risk of loss of reputation and the inability to build an effective system of communication with the environment.

An efficient communication system in crisis situations can minimize the negative effects of outflow of funds and become a peculiar alternative to tools for maintaining an appropriate level of production and sales. 
The core of the enterprise's communications system during the crisis period is anti-crisis Public Relations. This term means a clearly defined and regulated procedure for measures and communication mechanisms aimed at eliminating the negative interpretation of crisis phenomena.

Public relations can be interpreted in the broad (public) and narrow (marketing) sense. In broad terms, this term is considered as an activity aimed at reaching agreement between people on the basis of the formation and management of public opinion. In the narrow sense, this term is considered as an activity aimed at forming and maintaining a positive image of the enterprise, the conviction of the target groups in its reliability, expansion of contacts and ligaments.

\section{Results and Discussion}

The purpose of the crisis-based public relations is to stabilize the reputation of the company as a priority measure in achieving the strategic goal of stabilizing the financial condition of the enterprise. The experts singled out the following basic principles of anti-crisis communications:

- communications are the result of pre-thought-out and planned steps, not of improvisation;

- taking into account the time factor;

- the logic of the de-dramatization of the situation [4].

It should be noted that the main reputational problems of the enterprises are associated with adaptation to the new conditions, so we can state the existence of a crisis adaptation of the enterprise. Such a concept as "anti-crisis immunity" is a result of the successful adaptation of enterprises to new realities of development and overcoming the crisis situation in the field of communicative activity. A similar characteristic of the enterprise's image is formed as a result of the successful overcoming of crisis situations.

The main instrument of anti-crisis public relations is the anti-crisis program, which is a strategic document, or a plan of action in case of crisis situations. The purpose of such a program is not only to overcome, but also to prevent the crisis and restore the lost position of the enterprise. The anti-crisis program should contain the following main components (Fig. 1).

\section{Anti-crisis program}

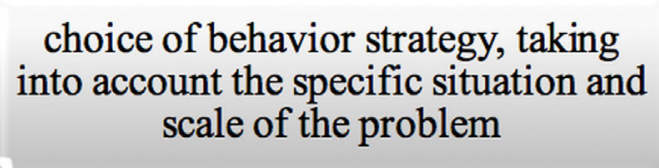

list of possible risks and threats for the reputation of the company

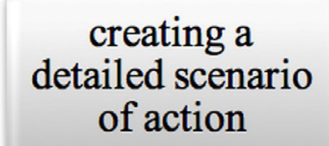

formation of a team that has to implement the planned activities

Fig.1. The components of anti-crisis communication program of the enterprises. 
Taking into account the main components of the anti-crisis communication program, we propose such a mechanism for the functioning of the anti-crisis communication system (fig.2).

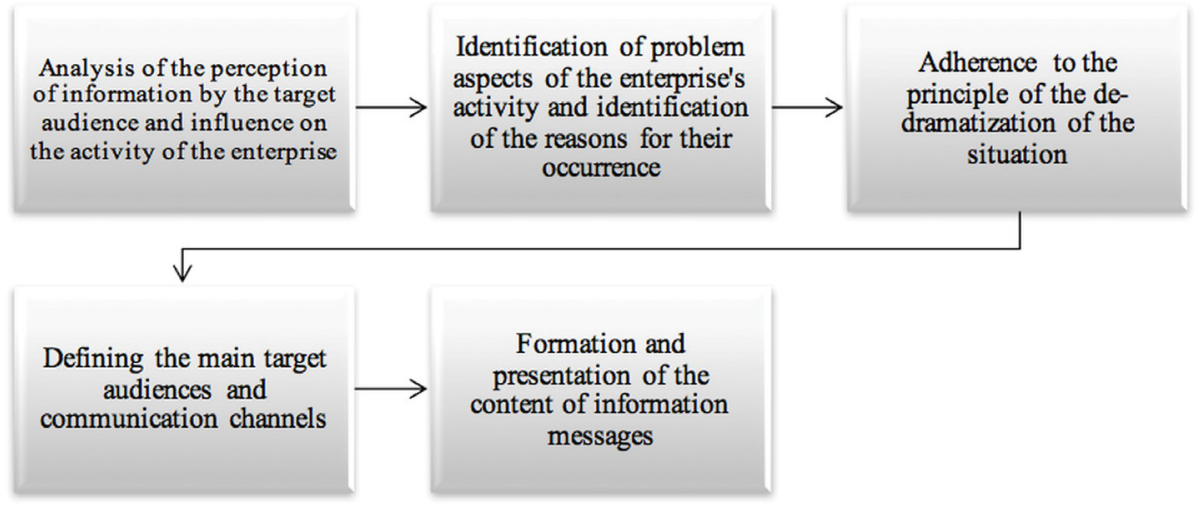

Fig.2. Mechanism of functioning of anti-crisis communication system of enterprise.

The scheme implies the feedback, which provides an opportunity to assess the effectiveness of communication activities and corrective actions. It should also be emphasized that anti-crisis communication policy should be conducted taking into account the basic principles of perception of information in the context of the crisis.

The basic principle is stereotyping. Stereotyped perception includes the emotional aspect (strong emotional instability, fear, distrust, suspicion) and the cognitive aspect (the desire to simplify the information, the schematics of the assessment of facts, the selectivity of perception, which determines its narrowed nature). There is also a phenomenon of group identification and unity. On the other hand, these psychological peculiarities also have a positive point: schematics and simplification contribute to an operational response to positive information of the enterprise and adaptation to crisis conditions.

Taking into account the above, we have proposed our own vision of a strategy for constructing anti-crisis communications, depending on the specific manifestations of the crisis (Table 2).

Table 2. Basic anti-crisis communication strategies.

\begin{tabular}{|l|l|l|l|}
\hline $\begin{array}{c}\text { The degree of } \\
\text { influence of crisis } \\
\text { phenomena on } \\
\text { the activities of } \\
\text { the enterprise }\end{array}$ & Content of the message & \multicolumn{1}{c|}{$\begin{array}{c}\text { Communication } \\
\text { channels }\end{array}$} & \multicolumn{1}{c|}{$\begin{array}{c}\text { Target } \\
\text { audience }\end{array}$} \\
\hline $\begin{array}{l}\text { Significant } \\
\text { deterioration in } \\
\text { the quality of } \\
\text { goods and } \\
\text { services produced }\end{array}$ & $\begin{array}{l}\text { Enterprise has powerful } \\
\text { anough leverage to } \\
\text { influence its employees and } \\
\text { implement quality control }\end{array}$ & $\begin{array}{l}\text { Printed } \\
\text { media, Internet } \\
\text { resources, back door- } \\
\text { to-end communication } \\
\text { channels, in particular } \\
\text { profile quality } \\
\text { journals }\end{array}$ & $\begin{array}{l}\text { Consumers, } \\
\text { corporate } \\
\text { clients }\end{array}$ \\
\hline $\begin{array}{l}\text { Loss-taking, staff } \\
\text { reduction }\end{array}$ & $\begin{array}{l}\text { Losses incurred by the } \\
\text { enterprise are caused by } \\
\text { temporary difficulties. An }\end{array}$ & $\begin{array}{l}\text { Printed and electronic } \\
\text { media, internal } \\
\text { corporate }\end{array}$ & $\begin{array}{l}\text { Employees of } \\
\text { the company, } \\
\text { shareholders of }\end{array}$ \\
\hline
\end{tabular}




\begin{tabular}{|c|c|c|c|}
\hline & $\begin{array}{l}\text { enterprise is able to } \\
\text { generate a sufficient cash } \\
\text { flow to cover losses. } \\
\text { Rollover of business } \\
\text { activity will be balanced, } \\
\text { moderate and non-scale. }\end{array}$ & communication & $\begin{array}{l}\text { the enterprise, } \\
\text { institutional } \\
\text { lenders, expert } \\
\text { environment }\end{array}$ \\
\hline $\begin{array}{lr}\text { Failure to fulfill } \\
\text { obligations } \\
\text { lenders }\end{array}$ & $\begin{array}{l}\text { Temporary problems with } \\
\text { returning funds. An } \\
\text { enterprise has the ability to } \\
\text { balance liquidity by } \\
\text { reaching agreements with } \\
\text { creditors on extending } \\
\text { maturities and attracting } \\
\text { funds. }\end{array}$ & $\begin{array}{l}\text { Printed business mass } \\
\text { media, Internet } \\
\text { resources, back door } \\
\text { intercompany } \\
\text { communication } \\
\text { channels, intra } \\
\text { corporate } \\
\text { communication }\end{array}$ & $\begin{array}{l}\text { Consumers, } \\
\text { corporate } \\
\text { clients, } \\
\text { company } \\
\text { shareholders, } \\
\text { institutional } \\
\text { lenders, expert } \\
\text { environment }\end{array}$ \\
\hline
\end{tabular}

It is worth emphasizing that the main condition for the effectiveness of anti-crisis communication measures is the complex use of elements of the specified communication system. The key task of the anti-crisis communication program is to provide an efficient combination of these elements. Note that domestic practice indicates the need for a balanced and systematic approach to the creation and use of anti-crisis communication program. On the other hand, this tool must have high flexibility and adaptability to changes in the operating environment of the enterprise.

The best example is the communication policy of the international company Philips, whose department was ready to finance the economic crisis of 2008-2009. Faced with the problem of reducing profits, the impossibility of obtaining bank loans and the need to restructure the business and reduce staff, the company set itself the goal - prevent panic in any Philips representative office. The "Vision 2010" program was developed, in which the information on the current state of the company was publicly disclosed and the top management was urged to seriously and easily deal with this situation. At the same time, the leadership took into account the need for both external communications (media, partners, clients) and internal (management and personnel), which is also an extremely important condition for the proper construction of anti-crisis PR strategy.

Another bright example is Pandora company. Pandora brought to the market a new direction and became a jewelry company Zara (a Spanish company, the world's largest manufacturer and seller of clothes). On the first stage of its development the company had huge losses. And top-management decided to refuse from large-scale advertising and focused on the distribution and development of the network. The focus was on the opening of concept stores, whereas in other countries Pandora developed mainly through sales in multi-brand formats, with a small number of its own boutiques. Another way to improve the efficiency of the network was the refusal to purchase equipment for new stores from a Danish franchisor - this helped reduce logistics costs. Pandora seeks to make its stores more interactive. So the new store in the World Trade Center in Manhattan is equipped with touch screens that customers can use to find information about the product. There is also a holographic device that displays 3D images of each charm. While Pandora is experimenting with these technologies 6 there are other innovations. In one of the shops, buyers can choose their own suspension.

An example of a successful PR-strategy during the crysis period is a comprehensive promotion program for DAIKIN Erope N.V. (European headquarters of the corporation DAIKIN, Japan). As a result of the implementation of the program, company managed to familiarize Central Asia with new DAIKIN products, strengthen its reputation, raise brand awareness, loyalty of dealers and consumers. The comprehensive program included a wide range of tools - from sponsoring thematic programs on TV to radio shows and quizzes, from articles in the print press and news on major Internet portals to large-scale PR events, 
developing a special site for partners and shooting video stories with consumer feedback [4].

In general, the main rule of anti-crisis communications - plan and only then action. After all, every step and every word, voiced by the communicator, have a significant significance for the nature of the crisis. The response to the crisis should be rapid and consistent - it will help take control of the situation and work with the consequences of the crisis, as well as prevent its deepening. Anti-crisis communications envisage open dialogue with the public, readiness to respond to media requests, systematic work to restore the image of the communicator, and create an information field that will reduce the gap between expectations in society and the real state of affairs.

\section{Conclusions}

Anti-crisis communication policy at the present stage becomes one of the main components of the model of crisis management of the enterprise. This tool provides the opportunity to stop the gradual deterioration of product quality, loss-making, and the inability to fulfill its obligations to shareholders. At the expense of effective communication policy, a positive information background is created around the company's activity, which ensures the restoration of confidence in it.

The main tool of the communication policy of the problem enterprise is the anti-crisis program, the basis of ensuring the functioning of which is a strategy for the formation of informational messages adequate to the crisis situation. The choice of an effective strategy for their formation, the use of optimal channels of communication and the identification of the key target audience are the main objectives of the anti-crisis communication program. In this case, it is necessary to differentiate the selected anti-crisis communication policy depending on the target audiences to which it is directed.

The main target audiences of the anti-crisis communication policy are enterprises market participants, employees of the problem enterprise, shareholders, large corporate clients, institutional lenders, expert environment. This policy is implemented through mass media, public events, intraregional intra-corporate communication and intra-corporate communication.

\section{References}

1. M. Fedotova, Communication with the public as an anti-crisis management: a manual (Publishing of the OmSTU, Omsk, 2009)

2. K. Snehal, Enterprise-managed wireless communication, U.S. Patent Application No. 11/538,042 (US Patent Buerau, Washington, 2014)

3. I. G. Pavlenko, Academic review, 1, 109-113 (2013)

4. O. O. Khandi, Marketing and Innovation Management, 4, 186-192 (2012) 